\title{
TERRACED LANDSCAPES IN SLOVAKIA
}

Jana Špulerová, Marta Dobrovodská, Dagmar Štefunková, Pavol Kenderessy, Martin Izsóff

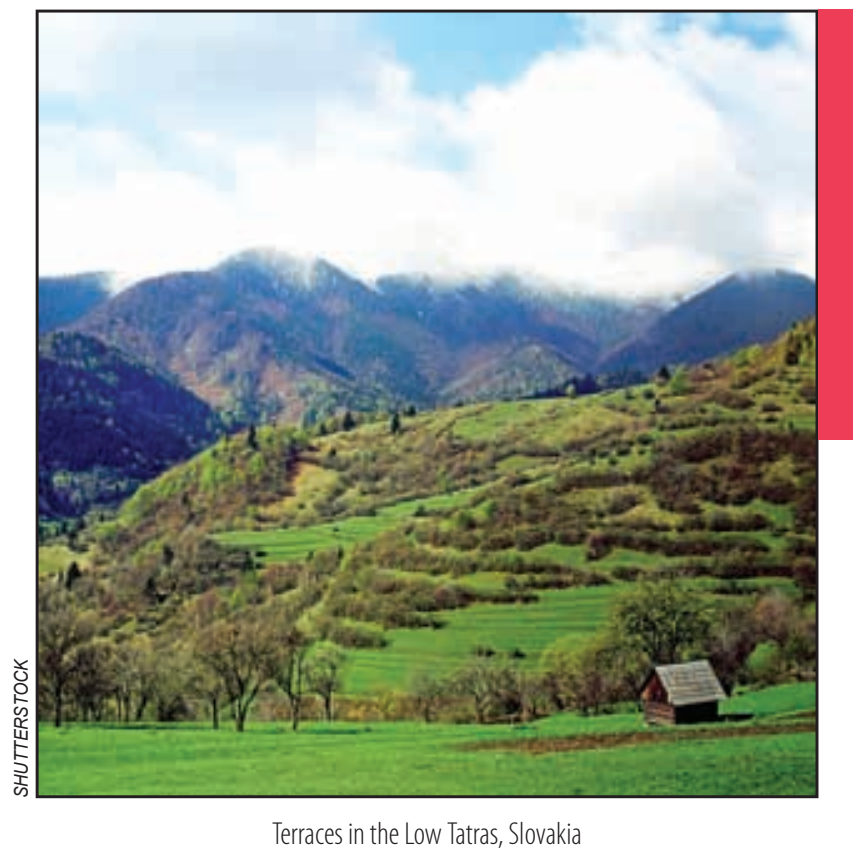




\section{Terraced landscapes in Slovakia}

DOI: http://dx.doi.org/10.3986/AGS.4674

UDC: $911.53: 631.613(497.6)$

COBISS: 1.01

ABSTRACT: This study investigates the distribution of terraced landscapes in Slovakia and analyzes their structural characteristics and land use. We found that traditional farming and terrace building as a part of agricultural intensification resulted in two types of terraced landscapes: historical terraced landscapes and new terraced landscapes. The two types differ in size, structure of various elements, their management intensity, and the impact of these spatial structures on biodiversity. Historical terraced landscapes in Slovakia have been partially preserved in vineyard regions, but they are mainly found in mountainous areas. New terraced landscapes are mainly linked to vineyard landscapes. The plant species composition on the mapped terraced landscapes shows a high diversity of habitats and terraces as agrarian relief forms create islands of species diversity in extensively managed agricultural landscapes.

KEY WORDS: terraced landscape, traditional agricultural landscape, agrarian relief forms, terraces, collectivization, Slovakia

This article was submitted for publication on $23^{\text {rd }}$ August, 2016.

\section{ADDRESSES:}

Jana Špulerová, Ph.D.

Institute of Landscape Ecology

Slovak Academy of Sciences

Štefánikova 3, SK - 81499 Bratislava, Slovakia

E-mail: jana.spulerova@savba.sk

Marta Dobrovodská, Ph.D.

Institute of Landscape Ecology

Slovak Academy of Sciences

Štefánikova 3, SK - 81499 Bratislava, Slovakia

E-mail: marta.dobrovodska@savba.sk

\section{Dagmar Štefunková, Ph.D.}

Institute of Landscape Ecology

Slovak Academy of Sciences

Štefánikova 3, SK - 81499 Bratislava, Slovakia

E-mail: dagmar.stefunkova@savba.sk

\section{Pavol Kenderessy, Ph.D.}

Institute of Landscape Ecology

Slovak Academy of Sciences

Štefánikova 3, SK - 81499 Bratislava, Slovakia

E-mail: pavol.kenderessy@savba.sk

\section{Martin Izsóff, M.Sc.}

Faculty of Natural Sciences

Constantine the Philosopher University in Nitra

Tr. A. Hlinku 1, SK - 94901 Nitra, Slovakia

E-mail: martin.izsoff@savba.sk 


\section{Introduction}

Due to natural conditions, such as mild climate and varied topography agriculture represents the most dominant activity of its inhabitants since the earliest colonization of Slovakia (Špulerová et al. 2014b). The south Slovakia - namely, the productive Danubian Lowland (Podunajská nízina) and the Eastern Slovak Lowland (Východoslovenská nízina) were settled first, whereas the mountains and border regions were settled and colonized later. In order to improve relief and soil quality, and to decrease both erosion and surface runoff on sloping terrain in less-suitable areas, terraces were built for cultivation. Terraced landscapes developed in various places around the world as a result of terraced farming (Agnoletti et al. 2011; Fischer et al. 2012). They have many environmental effects and often create specific habitats for biota (Babai et al. 2015). The construction and function of the various elements of terraced landscapes and their interactions were the particular focus of this article. Because terraces are the result of long-term utilization of parallel plateaus and grassy slopes, we consider them historical terraced landscapes. The importance of terracing systems in different traditional landscapes is highlighted as one of the most relevant traditional elements in the rural landscape (Barbera and Cullotta 2012), and we consider terraces to be agrarian relief forms. Current studies indicate that naturally less-fertile soils were improved by terracing and long-term cultivation (Slámová et al. 2015). Dry stone walls were used as retaining structures (Petit, Konold and Höchtl 2012). Because gully erosion in traditional agricultural landscapes is controlled by the course of anthropogenic linear features such as unpaved field and forest roads and balks in arable land, terracing usually mitigates erosion (Saksa and Minar 2012). The distribution of terraced landscapes is also related to the geological substrate and slope processes (Barančoková and Barančok 2015). Because large parts of the agricultural landscape were transformed by intensification of agriculture in the second half of the twentieth century, agrarian terraces as the oldest relics of traditional agricultural land use remained only in remote, less-accessible, and less-fertile localities or in areas with significant slope inclination (Štefunková and Dobrovodská 2009; Ivanova et al. 2011; Lieskovský et al. 2014).

In the second half of the twentieth century, new terraced landscapes were created through agricultural intensification. These terraces were built as terrain stages on an originally continuous slope in order to mitigate water erosion and allow more efficient mechanical cultivation on the flat part of the terrace (Štefunková and Hanušin 2016).

Traditional and new terraced landscapes are extraordinary landscaping that was used by man to deliberately reshape the landscape for his needs. They are also witnesses to technological and economic evolution in a particular historical period.

This study investigates the distribution of terraced landscapes in Slovakia and analyzes their structural characteristics, which may indicate differences between types of terraces and their role for man and the landscape.

\section{Methods}

The spatial distribution of historical terraced landscapes in Slovakia was acquired from a rural inventory of traditional agricultural landscapes (Špulerová et al. 2011), using visual interpretation of aerial photos and a field survey. As a result of this inventory we classified four types of traditional agricultural landscape with occurrence of terraces.

- I. Traditional agricultural landscapes with dispersed settlements;

- II. Traditional agricultural landscapes with vineyards;

- III. Traditional agricultural landscapes with arable land, grassland, and orchards; and

- IV. Traditional agricultural landscapes with arable land and grassland.

The presence of terraces and other agrarian relief forms was identified and studied in detail as part of the field survey.

Altogether, above 626 landscape sites of traditional agricultural landscapes recorded during the fieldwork, out of which 480 entries include terraced landscape. Regarding the manner of cultivation, content of the soil skeleton, and configuration of relief, we distinguished four agrarian relief forms of terraced landscape (Figure 1):

- Relief forms as a result of improvement of relief and soil quality: terraces or banked fields (historical or new terraces). Terraces were created in the course of long-term utilization of parallel plateaus and grassy slopes (balks). Banked fields were created through ploughing, without flattening the relief of arable fields; 

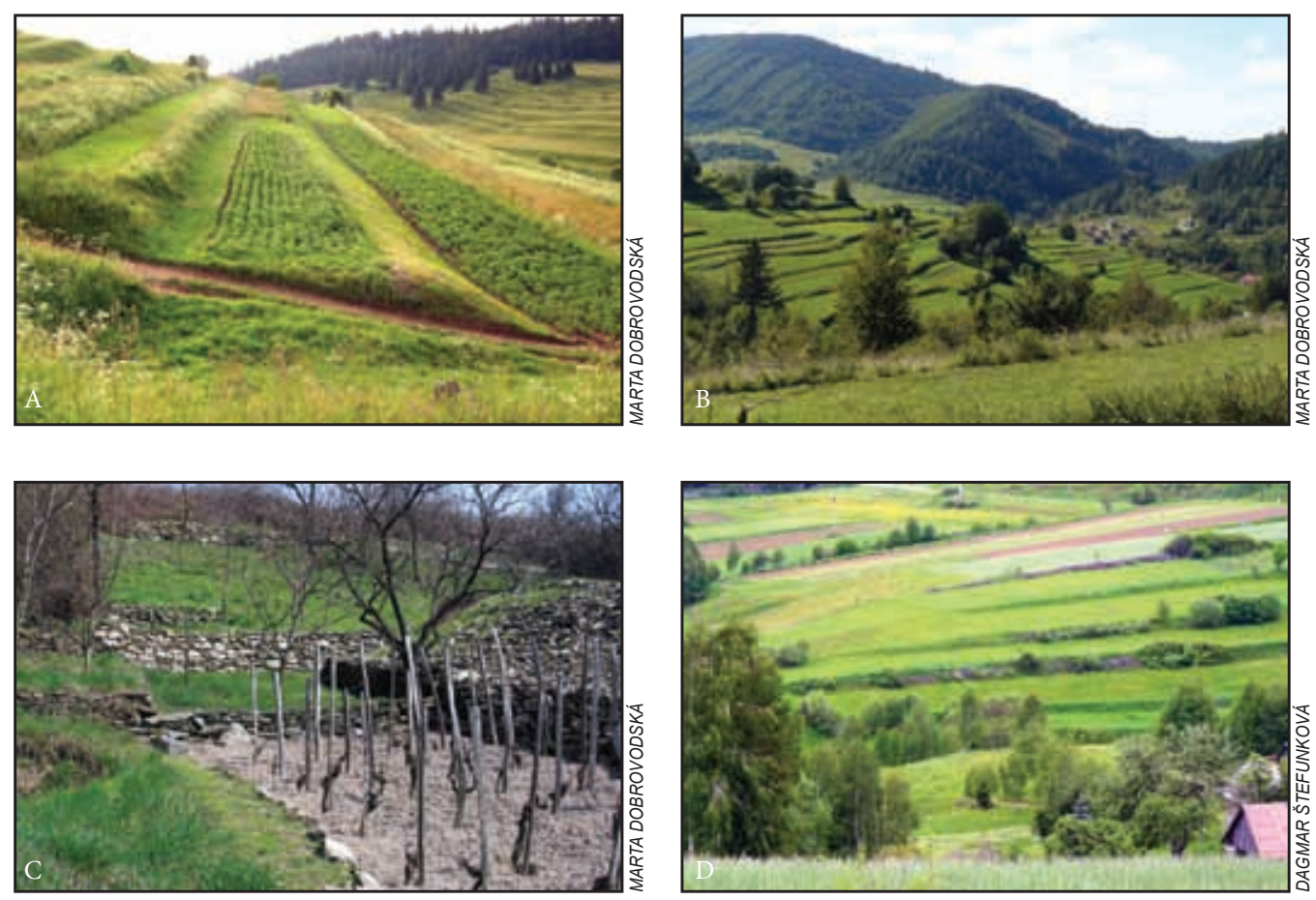

Figure 1: Agrarian relief forms of terraced landscape (A: terraces, B: banked fields, C: dry stone walls, D: slope mounds and heaps on terraces).

- Relief forms that are a result of soil-skeleton removal: dry stone walls were built from stones as supporting walls for vineyard terraces;

- Relief forms that are the result of both manners of soil cultivation: slope mounds and heaps occur on terraces or on banked fields, where stones from soil were removed and heaped onto the slope of the terraces or banked fields during yearly ploughing.

The agrarian relief forms were further characterized by the following features which were recorded in the field:

- Skeleton and soil content: 1) muddy, 2) muddy-rocky, 3) loamified rocky, 4) rocky (Figure 2);

- Width: average width of the soil/stone features by categories: 1) $<1 \mathrm{~m}, 2) 1.1-3 \mathrm{~m}, 3)>3 \mathrm{~m}$;

- Height: average height of soil/stone features by categories: 1) $<0.5 \mathrm{~m}, 2)$ 0.5-1 m, 3) $1.1-3 \mathrm{~m}, 4)>3 \mathrm{~m}$;

- Length: span length of soil/stone features (minimum and maximum of length) in meters;

- Continuity of banks: 1) continuous, 2) interrupted; interruptions are shorter than the fragments of a bank, 3) disconnected; interruptions are longer than fragments of a bank;

- Habitat: species richness on mapped agrarian relief form, species community belonging to the list of habitats with reference to the national habitat catalogue (Ružičková et al. 1996; Stanová and Valachovič 2002).

- Continuity of wood cover: 1) continuous; interruption of width is less than one time the vegetation height, 2) interrupted; interruption of width is two to four times the vegetation height, 3) disconnected; interruption of width is more than five times the vegetation height.

In order to determine the spatial distribution of new terraced landscapes in Slovakia, we used the CORINE Land Cover database (Pazur, Otahel' and Maretta 2015) and land cover data from the national Basic Geographic Information System (ZBGIS) by Maretta (Cadastre, Cartography and Land Surveying Office of the Slovak Republic, 2015). Terraces were identified by using visual interpretations of aerial photos. We divided them into three groups: 1) terraced vineyards, 2) abandoned terraced vineyards, and 3) other new terraced landscapes, usually covered by grassland or orchards. 

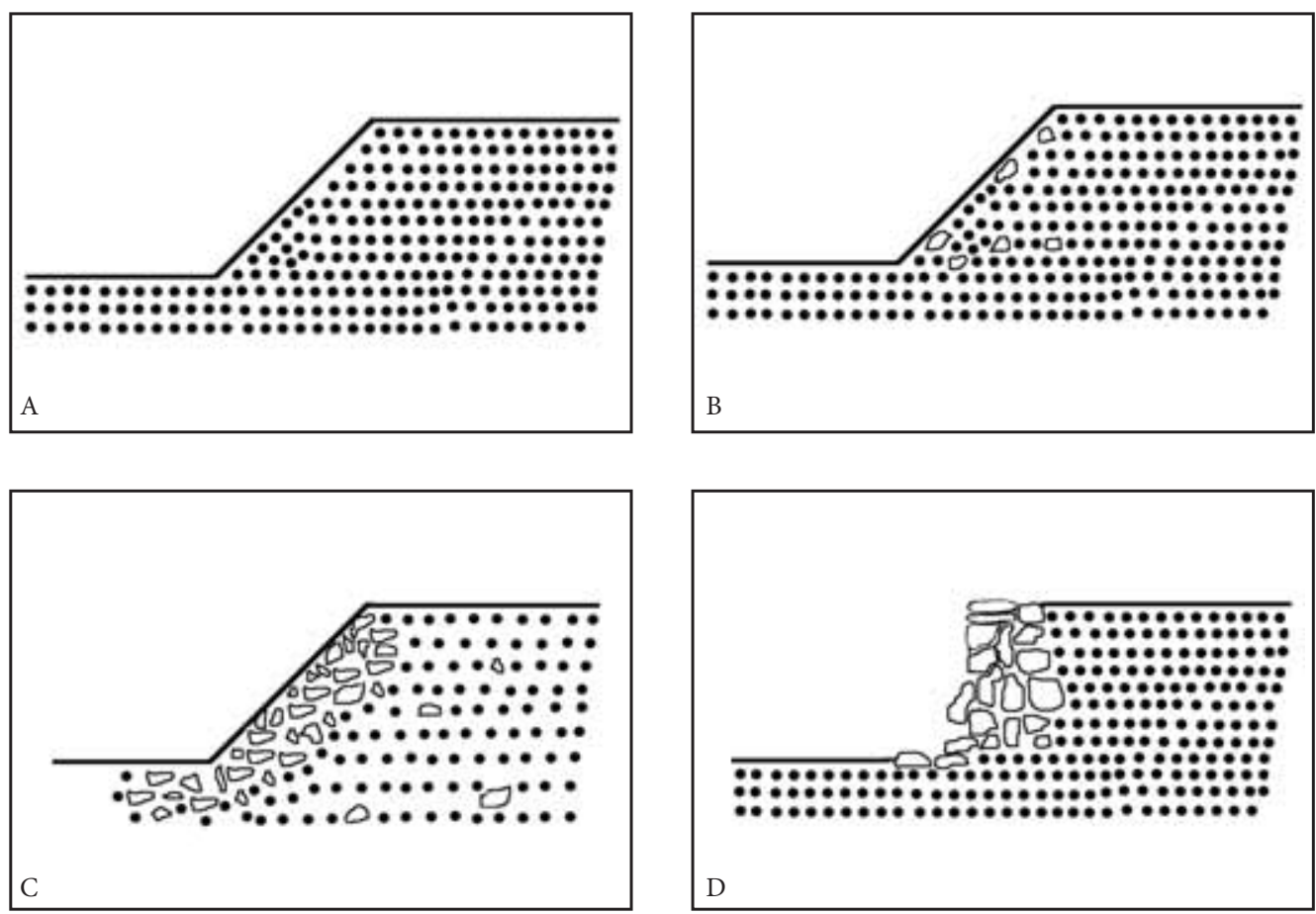

Figure 2: Skeleton and soil content of agrarian relief forms of terraced landscapes (A: muddy, B: muddy-rocky, C: loamified rocky, D: rocky).

\section{Results}

\subsection{Land use of terraced landscapes}

The terraced landscapes in Slovakia are a result of two different ways of land management focused on improving soil and relief condition. Long-term traditional farming has caused the origin of historical terraced landscapes. The terrace building as a part of agricultural intensification resulted in new terraced landscapes.

Historical terraced landscapes are usually extensively managed and consist of a patchwork of unique small-scale arable fields and permanent agricultural cultivations such as grassland, vineyards, and orchards.

Historical terraced landscapes have also been partially preserved in vineyard regions with a warmer climate (type II, traditional agricultural landscape of vineyards), but are mainly found in mountain areas with a cold climate on steep slopes and on shallow and skeletal soils (other types of traditional agricultural landscapes).

Historical terraced landscapes with vineyards create a patchwork of vineyards, often combined with orchards, grassland, and occasionally arable fields. They are mostly used for viticulture, or for other crops such as vegetables, fruit, potatoes, and cereals. They are distributed in southern Slovakia in the following natural - settlement nodal regions (regióny) (Miklós 2002): Lower Hron-Lower Ipel'(Hont) (DolnohronskoDolnoipelský (Hontský) región), Lower Zemplín (Dolnozemplínsky región), Gemer-Novohrad (GemerskoNovohradský región), Košice (Košický región), Danube (Podunajský regón), Nitra (Ponitriansky región), Trnava (Trnavský región), and Záhorie (Záhorský región). Infrastructure and buildings such as vineyard houses, cellars with vacation houses, and cottages are also a significant element of this small-scale structures because their presence is correlated with their management intensity. Where buildings are present, the patterns of agricultural mosaic are usually regularly managed and this management directly supports maintenance of the traditional landscape. Wine taverns and wine cellars are typical small architectural elements for the vineyard landscapes; however these were often expanded and rebuilt into weekend houses. 


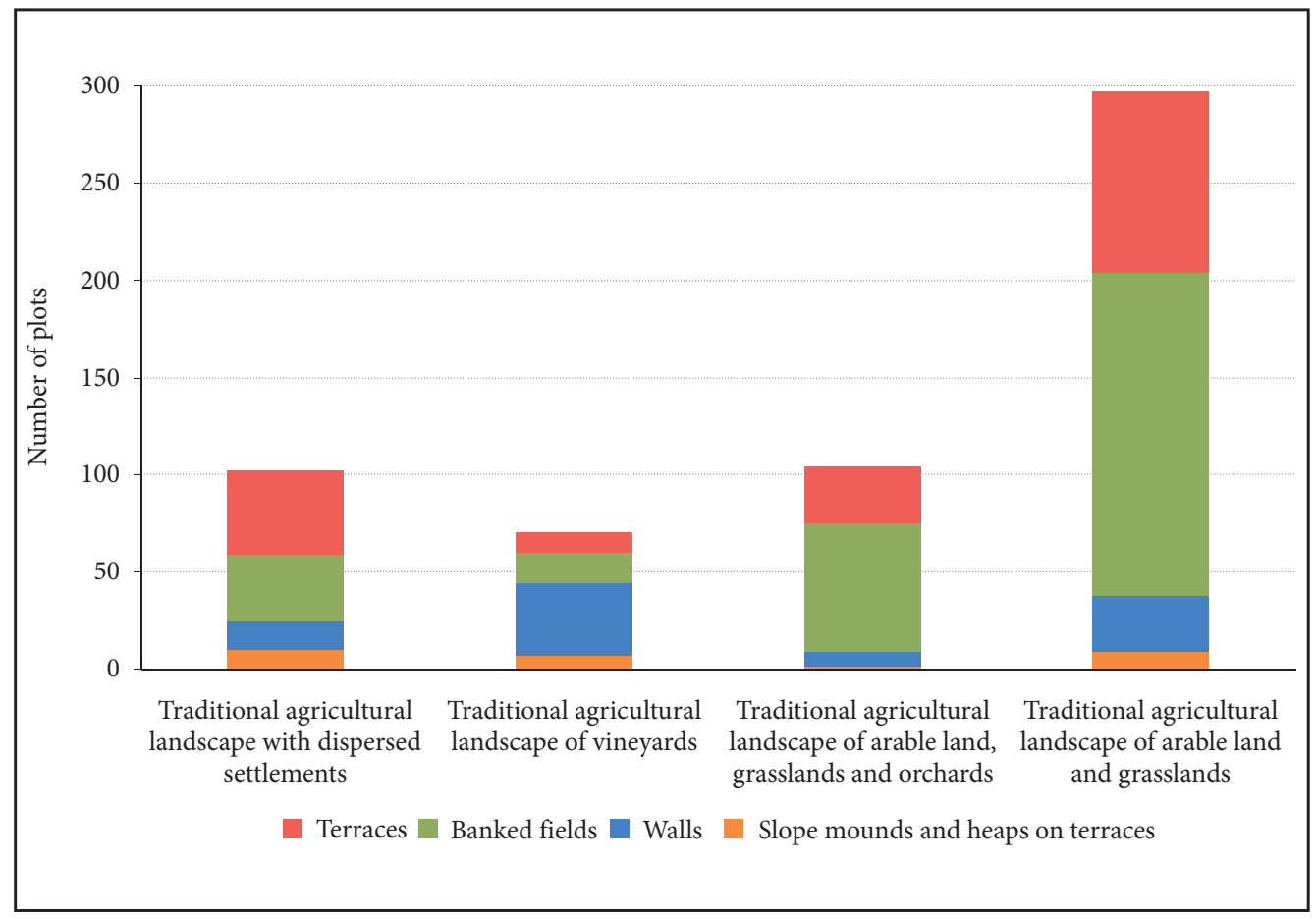

Figure 3: The presence of agrarian relief forms in traditional agricultural landscapes of Slovakia.

Figure 4: The area (in hectares) and share of characteristic types

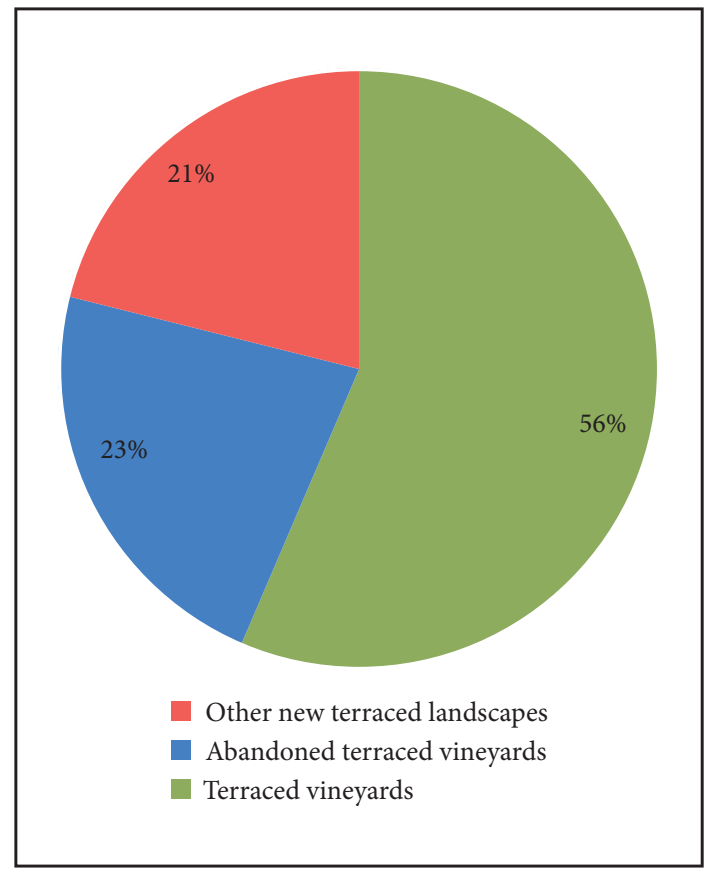
of new terraced landscapes. 
The mountain terraced landscapes occur in other three types of traditional agricultural landscapes (with dispersed settlement - type I, with orchards - type III or with arable land and grassland - type IV). They are characterized by a cold climate, steep slopes, and less-fertile soil, and therefore they are not very suitable for intensive agriculture. They consist of a patchwork of arable land, orchards, and grassland. They are primarily used for producing hay, vegetables, fruit, potatoes, and cereals. Due to declining management, they have often been transformed into grassland and their heterogeneous patterns are becoming rare. They are threatened by abandonment or construction. Hay barns, springs, and shelters have rarely remained in the traditional agricultural landscape of arable land and grassland.

New terraced landscapes are mainly linked to vineyard landscapes and rarely to other agricultural production. New terraces were created in the second half of the twentieth century and are intensively managed. They usually consist of a vineyard monoculture, and some of them were abandoned and overgrown with grass after 1990 (Figure 4). They are prevalent in the Little Carpathian Mountains (Malé Karpaty) and in south-central Slovakia on slopes with an incline greater than $6^{\circ}$. The new terraced landscape with orchards and/or grassland were mapped in Spiš region (Spišský region).

\subsection{Main features of terraced landscapes}

The largest group of agrarian relief forms are banked fields and terraces, which mainly occur in the traditional agricultural landscape of arable land, grassland, and orchards (type IV). The most valuable terraced landscapes feature dry stone walls, which are mainly found in the traditional agricultural landscape of vineyards (type II) and less frequently in the traditional agricultural landscape with dispersed settlements (type I) (Figure 3).

We differentiated agrarian relief forms in terms of the proportion of rocky material in the substrate, size parameters (width, height, and length), and plant species composition (Figures 5,6). The terraces and banked fields were gradually formed on the edge of the plot through ploughing, and they are characterized by muddy or muddy-rocky skeleton content. Rocky content is typical for two other agrarian relief forms: walls and slope mounds/heaps on terraces. The height of agrarian relief forms ranges at most from 1.1 to $3 \mathrm{~m}$, and the width mostly exceeds $3 \mathrm{~m}$.

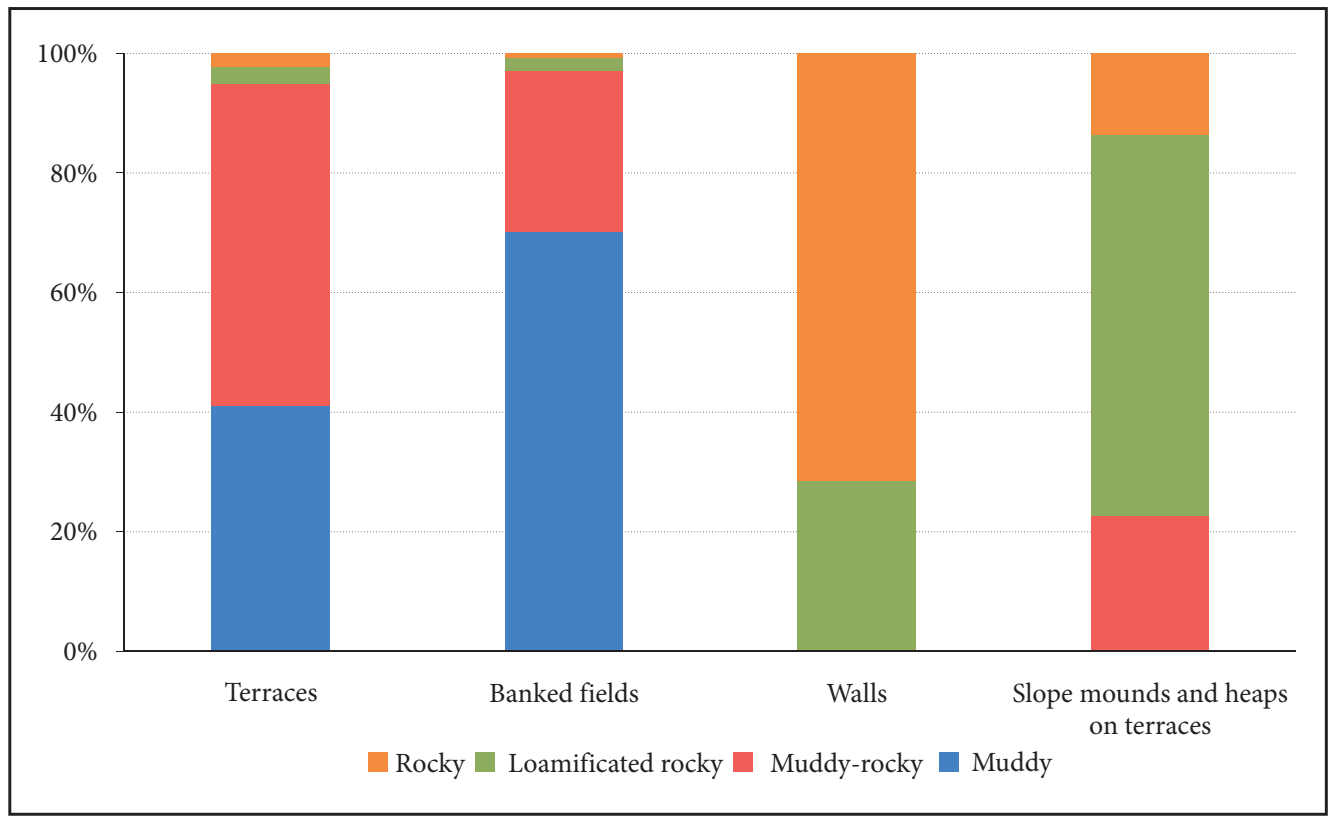

Figure 5: Skeleton content of agrarian relief forms in historical terraced landscapes. 


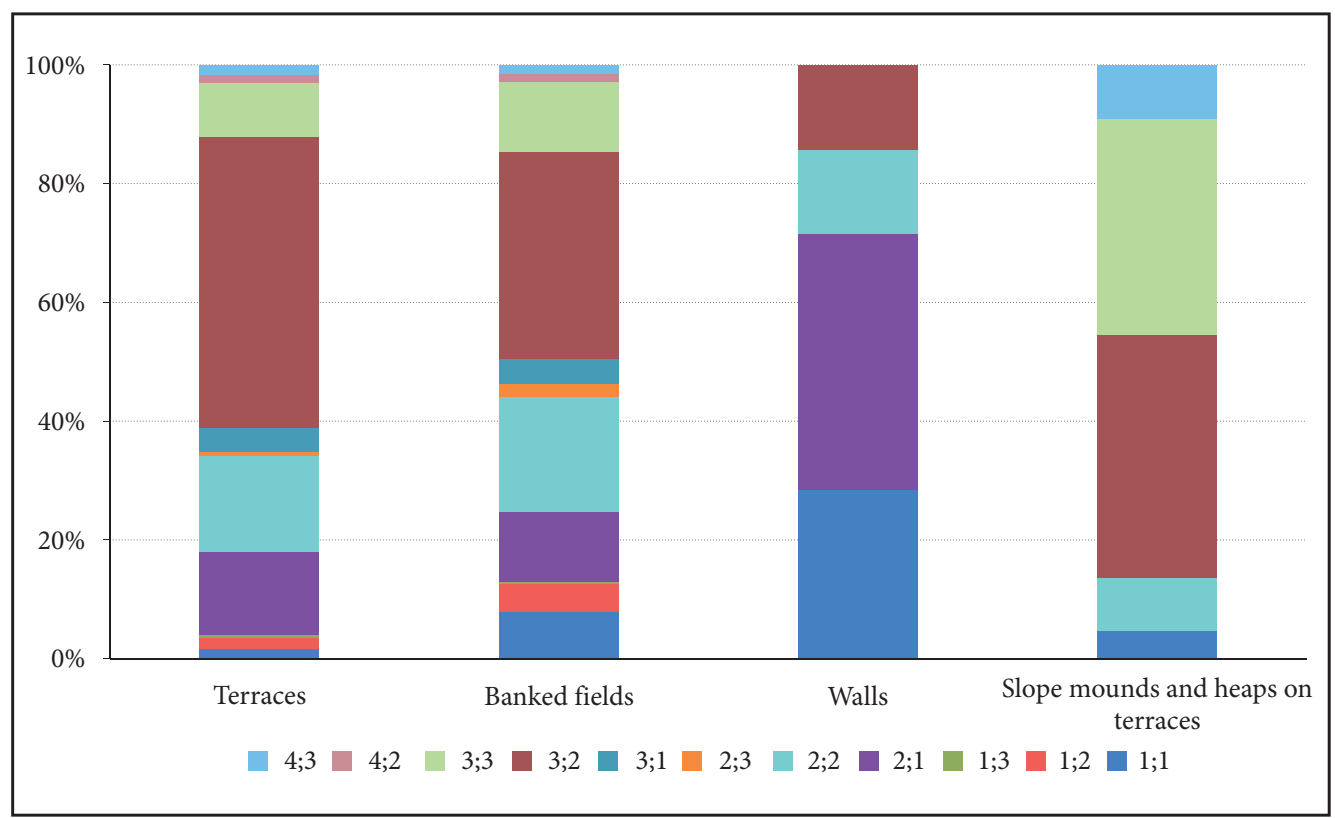

Figure 6: Parameters of historical terraced landscapes.

Legend: First number: height category: 1) $<0.5 \mathrm{~m}, 2) 0.5-1 \mathrm{~m}, 3) 1.1-3 \mathrm{~m}, 4)>3 \mathrm{~m}$; second number: width category: 1) $<1 \mathrm{~m}, 2) 1.1-3 \mathrm{~m}, 3)>3 \mathrm{~m}$ ).

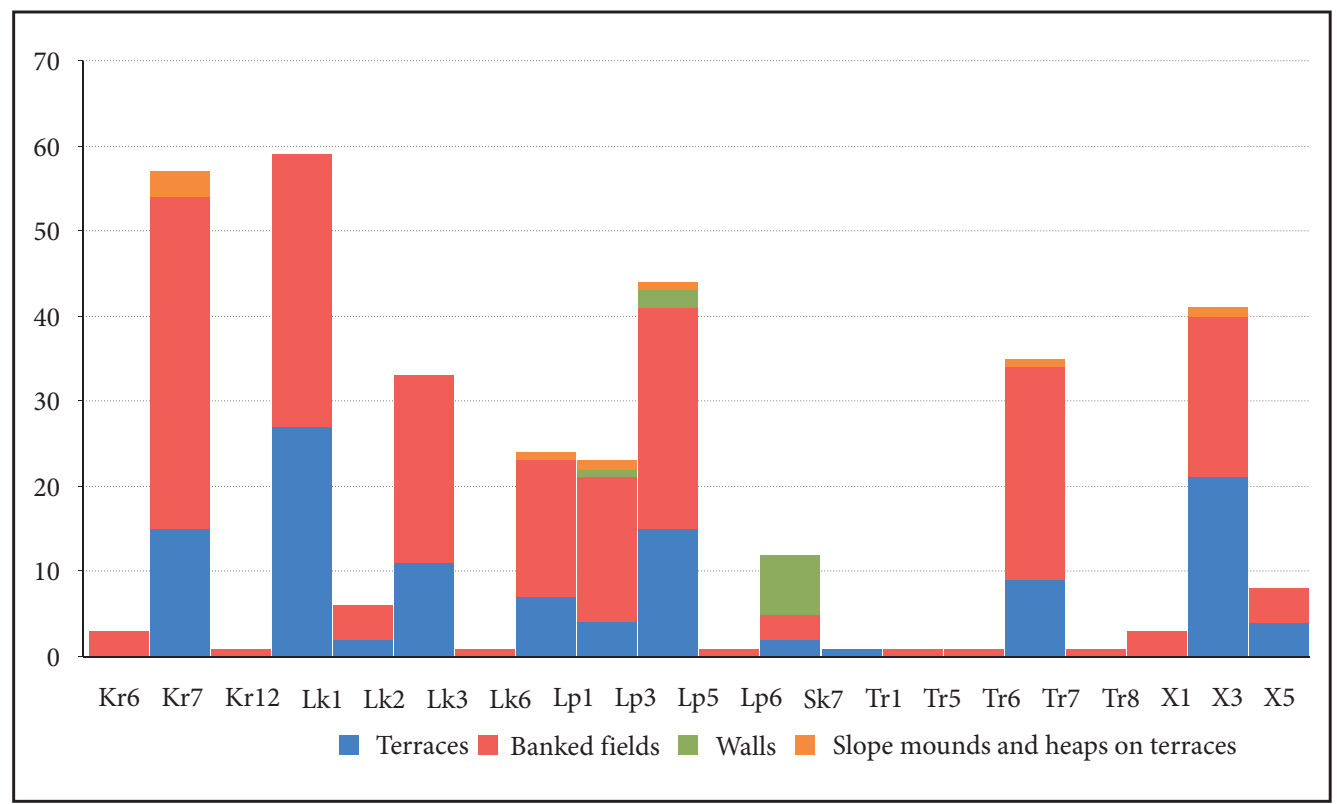

Figure 7: Vegetation on terraced agrarian relief forms.

Legend: Habitats: Kr6 Continental deciduous thickets, Kr7 Temperate thickets and scrub, Lk1 Lowland hay meadows, Lk2 Mountain hay meadows, Lk3 Mesophile pastures, Lk6 Eutrophic humid grassland, Lp1 Lines of planted fruit trees, Lp3 Lines of domestic deciduous trees, Lp5 Lines/remnants of mixed succession wood species, Lp6 Line/remnants of invasive woody species ( Ailanthus altissima, Negundo aceroides, and others), Sk7 Secondary rocky habitats, Tr6 Xeri-thermophile fringes, Tr7 Mesophile fringes, Tr8 Mat-grass swards, X1 Herbaceous clearings, X3 Ruderal communities, X5 Field margin cropland. 
Previous studies show that agrarian relief forms create islands of species diversity in extensively managed traditional agricultural landscapes (Ružičková et al. 1996; Imrichová 2006; Aavik and Liira 2009; Špulerová et al. 2014a). The plant species composition on the mapped terraced landscapes shows a high diversity of habitats, from open secondary screes and rocky habitats through ruderal communities and semi-natural grasslands to shrubby habitats, lines of trees, or other small woody patches (Figure 7). Because some habitat relevés could not be assigned to a particular syntaxon, but are affected by human activities or various phases of succession development between grassland, scrubland, and forest, we did not include them in the figure.

Banked fields were most often formed by communities of temperate thickets and scrub (Kr7) or lines/remnants of mixed succession wood species (Lp5). If agrarian relief forms were managed, they were usually covered by lowland hay meadows (Lk1) or mesophile pastures (Lk3). The presence of arable land was often accompanied by the occurrence of ruderal communities (X3). Species richness depends on complex factors and corresponds to certain abiotic factors, habitat types, aspects, and methods of cultivation.

The biodiversity of new terraced landscapes is generally lower due to intensive use of heavy machinery and intensive fertilization. However, in some areas landscape diversity has increased due to building new terraces during the communist era (Hanušin and Štefunková 2015).

\section{Discussion and conclusion}

Terraced landscapes were originally created mainly to protect and improve the soil quality and agricultural productivity in regions with unfavorable natural conditions. The ecosystem effects of such a specific landscape type have changed significantly. From the production point of view, they do not play an important role in sustaining food provision for local communities. In the case of terraced vineyards, their production and soil protection function remains an important issue. Today many terraced landscapes face two main threats: abandonment and subsequent succession (Gelencsér, Vona and Centeri 2012; Gellrich et al. 2007) or expansion of construction areas if they are located near large settlements.

Building various "steps" or terraces was the practice of cutting flat areas out of a hilly or mountainous landscape in order to grow crops. This type of farming influenced the development of various habitats. As a result of long-term utilization and management of the traditional agricultural landscape and extensive management practices, it can generally be concluded that traditional agrarian relief forms are overgrown by semi-natural or natural vegetation and that they increase the overall landscape ecological value of these landscapes. The biodiversity of newly created terraced landscapes is lower, but new terraced landscapes also increase overall landscape diversity and stability compared to intensified large block fields.

The preservation of such landscapes mostly depends on tradition and is highly dependent on the demographic situation. After decades of their utilization in changing social and economic conditions, the question is what their role and function would be today (Lipský 1995; Liquete et al. 2015). Stakeholders' preferences could significantly influence the preservation of these landscapes (Howley, Donoghue and Hynes 2012). The same landscape type could provide different services based on the context of preferences. From this perspective, it is important to focus future research on assessing how terraced landscapes affect the ecosystem and especially how they are changing in order to justify their preservation. It is also very important to involve social research to investigate social preferences for utilizing such landscapes.

This patchwork of agrarian relief forms and small-scale arable fields or permanent agricultural cultivations comprises areas that are defined as farmland with a high natural value in the European Union (Andersen et al. 2003; Ažman Momirski and Kladnik 2015). These areas are of great value, both from the perspective of nature and heritage conservation, as well as with regard to landscape and aesthetic values (Urbanc, Gašperič and Kozina 2015; Smrekar, Polajnar Horvat and Erhartič 2016; Smrekar, Zorn and Komac 2016). It is necessary to pay special attention to them, to develop strategies for their preservation, and to learn from good practices of the past and good examples from other countries (Stanchi et al. 2012; Kravchenko et al. 2016).

ACKNOWLEDGEMENT: This paper is the result of project funding from the Slovak Research and Development Agency (Project No. APVV-0866-12, "Evaluation of ecosystem functions and services of the cultural landscape $\ll)$. 


\section{References}

Aavik, T., Liira, J. 2009: Agrotolerant and high nature-value species - Plant biodiversity indicator groups in agroecosystems. Ecological Indicators 9-5. DOI: http://dx.doi.org/10.1016/j.ecolind.2008.10.006

Agnoletti, M., Cargnello, G., Gardin, L., Santoro, A., Bazzoffi, P., Sansone, L., Pezza, L., Belfiore, N. 2011: Traditional landscape and rural development: comparative study in three terraced areas in northern, central and southern Italy to evaluate the efficacy of GAEC standard 4.4 of cross compliance. Italian Journal of Agronomy 6-1. DOI: http://dx.doi.org/10.4081/ija.2011.6.s1.e16

Andersen, E., Baldock, D., Bennett, H., Beaufoy, G., Bignal, E., Brouwer, F., Elbersen, B., Eiden, G., Godeschalk, F., Jones, G. 2003: Developing a high nature value farming area indicator. Report to the European Environment Agency. Copenhagen.

Ažman Momirski, L., Kladnik, D. 2015: The terraced landscape in the Brkini Hills. Acta geographica Slovenica 55-1. DOI: http://dx.doi.org/10.3986/AGS.1627

Babai, D., Tóth, A., Szentirmai, I., Biró, M., Máté, A., Demeter, L., Szépligeti, M., Varga, A., Molnár, A., Kun, R., Molnár, Z. 2015: Do conservation and agri-environmental regulations effectively support traditional small-scale farming in East-Central European cultural landscapes? Biodiversity and conservation 24-13. DOI: http://dx.doi.org/10.1007/s10531-015-0971-z

Barančoková, M., Barančok, P. 2015: Distribution of the traditional agricultural landscape types reflecting geological substrate and slope processes in the Kysuce Region. Ekológia (Bratislava) 34-4. DOI: http://dx.doi.org/10.1515/eko-2015-0031

Barbera, G., Cullotta, S. 2012: An inventory approach to the assessment of main traditional landscapes in Sicily (Central Mediterranean Basin). Landscape Research 37-5. DOI: http://dx.doi.org/10.1080/ 01426397.2011 .607925

Geoportal - State Administration of Land Surveying and Cadastre of the Slovak Republic, 2015.. Internet: https://www.geoportal.sk/en/zbgis-smd (8. 11. 2016).

Fischer, J., Hartel, T., Kuemmerle, T. 2012: Conservation policy in traditional farming landscapes. Conservation letters 5. DOI: http://dx.doi.org/10.1111/j.1755-263X.2012.00227.x

Gelencsér, G., Vona, M., Centeri, C. 2012: Losing agricultural heritage in rural landscapes - a case study in Koppány Valley Area, Hungary. European Countryside 2. DOI: http://dx.doi.org/10.2478/ v10091-012-0019-2

Gellrich, M., Baur, P., Koch, B., Zimmermann, N. E. 2007: Agricultural land abandonment and natural forest re-growth in the Swiss mountains: A spatially explicit economic analysis. Agriculture Ecosystems \& Environment 118/1-4. DOI: http://dx.doi.org/10.1016/j.agee.2006.05.001

Hanušin, J., Štefunková, D. 2015: Zmeny diverzity vinohradníckej krajiny v zázemí Svätého Jura v období 1896-2011. Geografický časopis 67-3.

Howley, P., Donoghue, C. O., Hynes, S. 2012: Exploring public preferences for traditional farming landscapes. Landscape and Urban Planning 104-1. DOI: http://dx.doi.org/10.1016/j.landurbplan.2011.09.006

Imrichová, Z. 2006: Impact of management practises on diversity of grasslands in agricultural region of middle Slovakia. Ekológia 25-1.

Ivanova, M., Michaeli, E., Boltiziar, M., Juhascikova, J. 2011: Analysis of landscape heterogeneity changes on the example of Hlinne, Vysny Zipov, and Zlatnik Village (eastern Slovakia) in the Period 1826-2006. Ekológia 30-2. DOI: http://dx.doi.org/10.4149/ekol_2011_01_269

Kravchenko, Y. S., Chen, Q., Liu, X., Herbert, S. J., Zhang, X. 2016: Conservation practices and management in Ukrainian mollisols. Journal of Agricultural Science and Technology 18-3.

Lipský, Z. 1995: The changing face of the Czech rural landscape. Landscape and Urban Planning 31, 1-3. DOI: http://dx.doi.org/10.1016/0169-2046(94)01034-6

Lieskovský, J., Kenderessy, P., Špulerová, J., Lieskovský, T., Koleda, P., Kienast, F., Gimmi, U. 2014: Factors affecting the persistence of traditional agricultural landscapes in Slovakia during the collectivization of agriculture. Landscape Ecology 29-5. DOI: http://dx.doi.org/10.1007/s10980-014-0023-1

Liquete, C., Kleeschulte, S., Dige, G., Maes, J., Grizzetti, B., Olah, B., Zulian, G. 2015: Mapping green infrastructure based on ecosystem services and ecological networks: A Pan-European case study. Environmental Science \& Policy 54. DOI: http://dx.doi.org/10.1016/j.envsci.2015.07.009

Miklós, L. 2002: Členenie prírodno-sídelných spádových regiónov. Atlas krajiny Slovenskej Republiky. Bratislava, Banská Bystrica. Internet: http://geo.enviroportal.sk/atlassr (25. 9. 2016). 
Pazur, R., Otahel', J., Maretta, M. 2015: The distribution of selected CORINE land cover classes in different natural landscapes in Slovakia: Methodological framework and applications. Moravian Geographical Report 23-1. DOI: http://dx.doi.org/10.1515/mgr-2015-0005

Petit, C., Konold, W., Höchtl, F. 2012: Historic terraced vineyards: impressive witnesses of vernacular architecture. Landscape History 33-1. DOI: http://dx.doi.org/10.1080/01433768.2012.671029

Ružičková, H., Halada, L., Jedlička, L., Kalivodová, E. 1996: Biotopy Slovenska: príručka k mapovaniu a katalóg biotopov. Bratislava.

Saksa, M., Minar, J. 2012: Assessing the natural hazard of gully erosion through a Geoecological Information System (GeIS): A case study from the Western Carpathians. Geografie 117-2.

Slámová, M., Jakubec, B., Hreško, J., Beláček, B., Gallay, I. 2015: Modification of the potential production capabilities of agricultural terrace soils due to historical cultivation in the Budina cadastral area, Slovakia. Moravian Geographical Reports 23-2. DOI: http://dx.doi.org/10.1515/mgr-2015-0010

Smrekar, A., Polajnar Horvat, K., Erhartič, B. 2016: The beauty of landforms. Acta geographica 56-2. DOI: http://dx.doi.org/10.3986/AGS.3039

Smrekar, A., Zorn, M., Komac, B. 2016: Heritage protection through an geomorphologist's eyes: From recording to awareness raising. Acta geographica 56-1. DOI: http://dx.doi.org/10.3986/AGS.875

Stanchi, S., Freppaz, M., Agnelli, A., Reinsch, T., Zanini, E. 2012: Properties, best management practices and conservation of terraced soils in Southern Europe (from Mediterranean areas to the Alps): A review. Quaternary International 265. DOI: http://dx.doi.org/10.1016/j.quaint.2011.09.015

Stanová, V., Valachovič, M. 2002: Katalóg biotopov Slovenska. Bratislava.

Špulerová, J., Dobrovodska, M., Lieskovský, J., Bača, A., Halabuk, A., Kohút, F., Mojses, M., Kenderessy, P., Piscová, V., Barančok, P. 2011: Inventory and classification of historical structures of the agricultural landscape in Slovakia. Ekológia 30-2. DOI: http://dx.doi.org/10.4149/ekol_2011_02_157

Špulerová, J., Dobrovodská, M., Štefunková, D., Bača, A., Lieskovský, J. 2014a: Biodiversity of traditional agricultural landscapes in Slovakia and their threats. Biocultural landscapes. Dordrecht.

Špulerová, J., Dobrovodská, M., Štefunková, D., Piscová, V., Petrovič, F. 2014b: Evolution of the traditional agricultural landscapes of Slovakia. Environment and ecology in the Mediterranean Region II. Newcastle.

Štefunková, D., Dobrovodská, M. 2009: Preserved European cultural heritage in agrarian landscape of Slovakia. Tájökológiai Lapok 7-2.

Štefunková, D., Hanušin, J. 2016: Analysis of the spatial and temporal distribution of selected landscape diversity indexes in detailed scale (example of viticultural landscape Svätý Jur). Landscape and landscape ecology : proceedings of the $17^{\text {th }}$ International Symposium on Landscape Ecology. Bratislava.

Urbanc, M., Gašperič, P., Kozina, J. 2015: Geographical imagination of landscapes: analysis of the book of photographs Slovenian landscapes. Acta geographica 55-1. DOI: http://dx.doi.org/10.3986/AGS.836 